\title{
Desain Kapal Layanan Publik Di Kepulauan Kangean, Kabupaten Sumenep
}

\author{
Ahmad Rif'an Nugraha Putra, dan Hesty Anita Kurniawati \\ Jurusan Teknik Perkapalan, Fakultas Teknologi Kelautan, Institut Teknologi Sepuluh Nopember (ITS) \\ Jl. Arief Rahman Hakim, Surabaya 60111 Indonesia \\ e-mail: tita@na.its.ac.id
}

\begin{abstract}
Abstrak-Kemajuan di bidang pembangunan infrastruktur, pendidikan, kesehatan adalah tolok ukur kemajuan satu bangsa. Di Negara Indonesia yang wilayahnya cukup luas dan terdiri dari pulau-pulau cenderung terjadi ketidakseimbangan pembangunan. Terutama di pulau-pulau kecil yang pembangunannya dirasa kurang. Dari sini perlu adanya pemikiran atau strategi khusus untuk memajukan pembangunannya terutama dibidang pelayanan publik.Ide kami adalah sebuah perancangan kapal layanan publik yang diharapkan mampu memajukan pelayanan publik di pulau-pulau kecil. Pelayanan publik yang ada dalam kapal ini adalah pengurusan Surat Izin Mengemudi (SIM), pembayaran pajak kendaraan atau Satuan Administrasi Manunggal Satu Atap (Samsat) dan puskesmas. Kepulauan Kangean yang secara geografis berada di timur pulau Madura, khususnya berada di wilayah kabupaten Sumenep. Sebagai wilayah kecamatan kepulauan, Kecamatan Arjasa dan Kecamatan Kangayan keduanya memiliki fasilitas pelayanan publik yang cukup terbatas. Tujuan dari Tugas Akhir ini adalah untuk mendapatkan desain konseptual kapal layanan publik untuk daerah kepulauan Kangean, Madura. Proses desain kapal dimulai dari survei lapangan untuk mendapatkan luasan ruangan pelayanan, pengunjung layanan, dan jenis pelayanan. Dari data tersebut didapat desain awal. Ukuran yang didapat harus memenuhi batasan seperti hukum Archimedes, freeboard, stabilitas, tonnage, dan memiliki harga yang minimum. Ukuran utama kapal yang di dapatkan adalah, $\mathrm{Lpp}=35.275 \mathrm{~m}, \mathrm{Bm}=8 \mathrm{~m}, \mathrm{H}=3.12 \mathrm{~m}, \mathrm{~T}=\mathbf{2} \mathrm{m}$, dengan biaya pembangunan sebesar Rp. 9.510.256.090. Dari data kapal tersebu kemudian dibuat Lines Plan, General Arrangement, Safety Plan dan 3D kapal.
\end{abstract}

Kata Kunci-desain kapal, kapal layanan publik, Kepulauan Kangean, Sumenep

\section{PENDAHULUAN}

$\mathrm{K}$ EMAJUAN di bidang pembangunan infrastruktur, pendidikan, kesehatan adalah tolok ukur kemajuan satu bangsa. Di Negara Indonesia yang wilayahnya cukup luas dan terdiri dari pulau-pulau cenderung terjadi ketidakseimbangan pembangunan. Terutama di pulau-pulau kecil yang pembangunannya dirasa kurang. Kepulauan Kangean yang secara geografis berada di timur pulau Madura, khususnya berada di wilayah kabupaten Sumenep terdiri dari gugusan pulau-pulau kecil yang banyak.

Sebagai wilayah kepulauan, kecamatan Arjasa dan Kangayan keduanya memiliki fasilitas kesehatan berupa puskesmas yang cukup terbatas. Data yang diperoleh dari BPS Sumenep menunjukkan bahwa fasilitas kesehatan dan tenaga kesehatan di Kecamatan Arjasa dan Kangayan terbatas. Disamping itu pelayanan lain yang sangat dibutuhkan olah masyarakat Kepulauan Kangean adalah pembuatan Surat Izin Mengemudi (SIM) dan Satuan Administrasi Manunggal Satu Atap (Samsat). Dimana untuk pembuatan SIM sendiri warga di Kepulauan Kangean harus menuju Polres Sumenep. Waktu yang harus di tempuh untuk menuju kota Sumenep berkisar 89 jam menggunakan kapal motor. Sedangkan untuk pelayanan pembayaran pajak kendaraan untuk Kepulauan kangean, Satuan Lalu Lintas Polres Sumenep bekerja sama dengan UPT Dipenda Jatim sumenep dan Bank Jatim Cab. Sumenep melaksanalkan kegiatan pelayanan samsat Payment Point di Kecamatan Arjasari Kepulauan Kangean Kabupaten Sumenep. Namun pelayanan ini hanya menjangkau pulau utama di Kangean, tidak untuk pulau-pulau kecil di sekitarnya yang juga berpenghuni.

Perlu adanya usaha agar penduduk tersebut dapat menikmati fasilitas pelayanan publik dengan keadaan geografis pulau tersebut, sehingga penggunaan fasilitas umum terapung adalah metode yang tepat dalam menjangkau penduduk pulau kecil. Untuk membangun kapal pelayanan publik harus disesuaikan dengan keadaan geografis daerah yang akan digunakan sebagai kawasan operasional kapal serta sistem kerja kapal tersebut. Oleh karena itu pada Tugas Akhir ini dilakukan perencanaan desain kapal layanan publik sebagai sarana pemberian bantuan terkait masalah pelayanan publik.

\section{TINJAUAN PUSTAKA}

Bentuk pelayanan publik yang diberikan kepada masyarakat dapat dibedakan ke dalam beberapa jenis pelayanan, yaitu:

1) Pelayanan Pemerintahan Adalah jenis pelayanan masyarakat yang terkait dengan tugas-tugas umum pemerintah, seperti pelayanan KTP, SIM, Pajak, dan keimigrasian.

2) Pelayanan Pembangunan Suatu jenis pelayanan masyarakat yang terkait dengan penyediaan sarana dan prasarana untuk memberikan fasilitas kepada masyarakat dalam melakukan aktifitasnya sebagai warga negara. Pelayanan ini meliputi penyediaan jembatan-jembatan pelabuhan, dan lain-lain.

3) Pelayanan Utilitas Adalah jenis pelayanan yang terkait dengan utilitas bagi masyarakat seperti, penyediaan listrik, air, telephon dan transportasi masal. 
4) Pelayanan Sandang, Pangan, dan Papan. Merupakan jenis pelayanan yang menyediakan bahan kebutuhan pokok masyarakat dan kebutuhan perumahan, seperti penyediaan beras, gula, minyak, gas, tekstil, dan perumahan murah.

5) Pelayanan Kemasyarakatan Yaitu jenis pelayanan masyarakat yang dilihat dari sifat dan kepentingannya lebih ditekankan pada kegiatan-kegiatan sosial kemasyarakatan, seperti pelayanan kesehatan, pendidikan, ketenagakerjaan, penjara, rumah yatim piatu dan lain-lain [1].

Proses desain merupakan proses yang dilakukan secara berulang-ulang hingga menghasilkan suatu desain yang sesuai dengan apa yang diinginkan. Dalam design process pembangunan kapal baru terdapat beberapa tahapan desain, yaitu antara lain [2]:

1) Concept design

2) Preliminary design

3) Contract design

4) Detail design

\section{TINJAUAN DAERAH OPERASIONAL}

Wilayah Kebupaten Sumenep terdiri dari 2 wilayah, yaitu Sumenep daratan dan Sumenep Kepulauan. Sumenep kepulauan terdiri dari 9 kecamatan dengan luas total 937,368 Km2. Pulau ini terletak di $6^{\circ}-7^{\circ}$ LS dan $115^{\circ} 10^{\prime}-115^{\circ} 44^{\prime} B T$. Luas pulau ini dan Kepulauan mempunyai luas 64.500,95 hektar. Pulau-pulau yang termasuk di wilayah ini adalah Pulau Sapeken, Pulau Mamburit, Pulau Paliat, Pulau Saubi, Pulau Sepapan, Pulau Sabuntan, Pulau Sepangkur, Pulau Saor, Pulau Saebus, Pulau Sasiil, Pulau Bangkao, Pulau Sadulang Kecil, Pulau Sadulang Besar, Pulau Pagerungan Besar, Pulau Pagerungan Kecil, dan Pulau Sepanjang.

Dalam perencanaan rute operasi Kapal melewati beberapa posko/node. Posko-posko ini merupakan tempat melakukan pelayanan publik, baik itu layanan jasa maupun layanan kesehatan. Dengan pertimbangan beberapa hal yang mendukung operasi kapal maka diperoleh 13 node atau titik operasi kapal yaitu titik-titik uyang akan disinggahi kapal layanan publik.

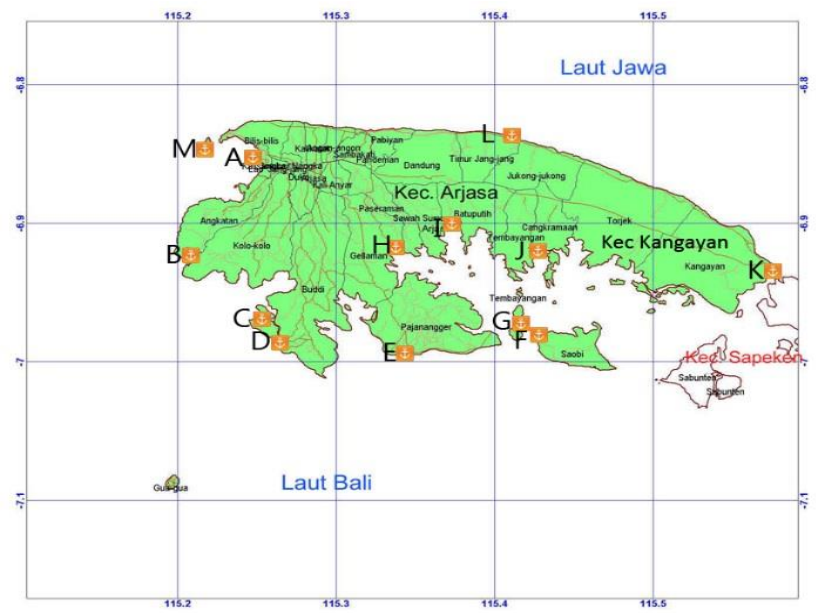

Gambar. 1. Titik/ node yang akan di singgahi kapal layanan publik.
Dalam perencanaan operasi kapal layanan publik ini akan mengadopsi operasi layanan dari SIM keliling, Samsat keliling maupun puskesmas keliling yang ada di darat. Puskesmas keliling melayani pasien sesui jam kerja, yaitu Senin-Sabtu. Untuk operasi Samsat dan SIM keliling di daerah surabaya beroperasi dari hari Senin - Jumat pada pukul 09.00-16.00, kecuali pada hari sabtu mulai dari pukul 09.00-21.00 [3].

Tabel 1.

Jadwal kerja kapal layanan publik.

\begin{tabular}{cc}
\hline \hline Rute & Jarak yang ditempuh $(\mathrm{nm})$ \\
\hline$A-B$ & 6 \\
$B-C$ & 6 \\
$C-D$ & 1 \\
$D-E$ & 5 \\
$E-F$ & 4 \\
$F-G$ & 2 \\
$G-H$ & 3 \\
$H-I$ & 3 \\
$I-J$ & 4 \\
$J-K$ & 8 \\
$K-L$ & 10 \\
$L-M$ & 13 \\
Total & 65 \\
\hline \hline
\end{tabular}

Tabel 2.

Jadwal kerja kapal layanan publik [4].

\begin{tabular}{cc}
\hline \hline Jute & Jarak yang ditempuh $(\mathrm{nm})$ \\
\hline$A$ & $07.00-11.30$ \\
$B$ & $13.00-17.00$ \\
$C$ & $07.00-11.30$ \\
$D$ & $13.00-17.00$ \\
$E$ & $07.00-11.30$ \\
$F$ & $13.00-17.00$ \\
$G$ & $07.00-11.30$ \\
$H$ & $13.00-17.00$ \\
$I$ & $07.00-11.30$ \\
$J$ & $13.00-17.00$ \\
$K$ & $07.00-11.30$ \\
$L$ & $13.00-17.00$ \\
$M$ & $18.30-21.00$ \\
\hline \hline
\end{tabular}

\section{ANALISIS TEKNIS}

Jurnal yang dikerjakan ini, pengambilan data dalam survei lapangan dilakukan di Polres Lamongan, kantor Samsat Lamongan dan Puskesmas Kecamatan Deket, Lamongan. Pertimbangan dalam mengambil data ke tempat ini adalah:

1) Tempat lebih dekat dengan pihak peneliti

2) Menghemat waktu

3) Mudah mendapatkan data

4) Jumlah warga yang hampir sama dengan Kepulauan Kangean

\section{A. Desain Awal}

Data yang diambil dari tempat pengurusan Surat Izin Mengemudi (SIM) di Polres Lamongan, kantor Satuan Administrasi Manunggal Satu Atap (Samsat) dan Puskesmas Kecamatan Deket, Lamongan adalah luasan dari ruanganruangan yang ada di kantor tersebut, antara lain:

1) Ruang layanan pembuatan SIM 
2) Ruang kantor Samsat

3) Ruang Layanan Puskesmas

Dari survey lapangan di dapatkan luasan ruangan-ruangan layanan publik yang di butuhkan untuk membuat desain awal kapal layanan publik. Namun luasan ruangan layanan yang ada di darat tidak sama dengan luasan ruangan layanan yang ada di kapal, karena lahan di kapal tidak seluas yang ada di darat.
Ukuran ruangan yang ada di darat di minimalisir agar bisa optimal. Tujuan pembuatan desain awal ini untuk mencari ukuran awal kapal yang dapat digunakan untuk perhitungan mencari ukuran utama kapal. Ukuran awal kapal dari desain awal dapat dilihat pada gambar 2 .

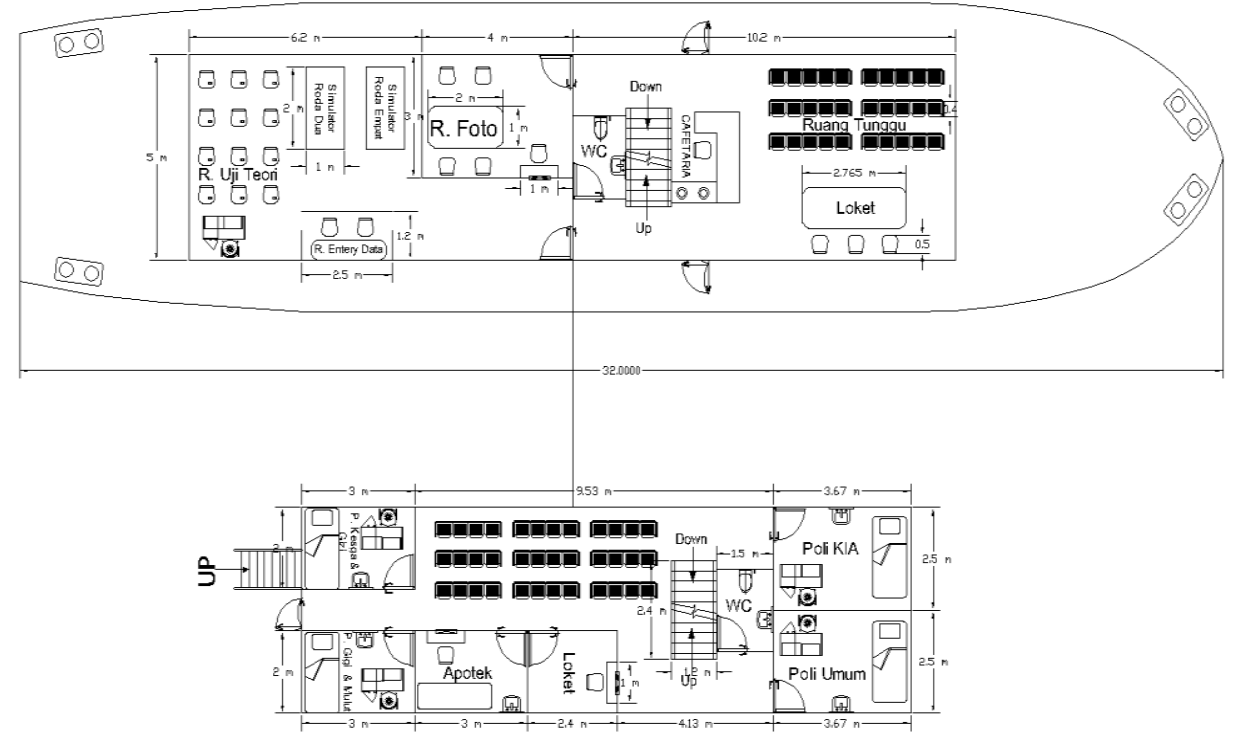

Gambar. 2. Desain awal

\section{B. Perhitungan Awal}

Dari desain awal kemudian dihitung perhitungan perhitungan awal yang terdiri dari:

1) Perbandingan ukuran kapal

2) Froude Number

3) Koefisien Blok

4) Koefisien midship

5) Koefisien prismatic

6) Koefisien waterplan

7) Longitudinal Center of Bouyency

8) Displasement

\section{Hambatan}

Kapal yang didesain ini menggunakan perhitungan hambatan dengan metode holtrop, berikut hasil perhitungannya:

$R_{T}=\frac{1}{2} \rho V^{2} S_{t o t}\left[C_{F}(1+k)+C_{A}\right]+\frac{R_{W}}{W} W$

dimana,

$R_{T}=18.170 \mathrm{kN}$

Dengan didapatkannya nilai $R_{T}$, maka dapat di cari nilai BHP. Untuk mencari BHP, dimulai dengan mencari daya yang keluar dari propeller yaitu EHP. Dari EHP dibagi dengan efisiensi-efisiensi sehingga muncul BHP. Nilai BHP yang di dapat adalah 261.044 HP. Dengan BHP inilah dapat memilih mesin dan genset yang akan dipakai.

\section{LWT (Light Weight Tonnage)}

LWT merupaka berat kapal kosong yang terdiri dari berat baja, berat perlengkapan, dan berat permesinan kapal. Berat yang dihitung sampai geladak yang teratas [5]. Dari hasil perhitungan didapatkan harga LWT sebesar 236.196 ton.

\section{E. DWT (Dead Weight Tonnage)}

DWT merupakan berat mati kapal yaitu muatan maksimum yang dapat diangkut. Yang termasuk dalam perhitungan DWT adalah total dari berat muata, kru dan barang bawaan, berat consumable dan payload. Dari hasil perhitungan didapat harga DWT sebesar 99.485 ton.

\section{F. Freeboard}

Perhitungan freeboard standar mengacu pada Peraturan Standar Kapal Non Konvensi Berbendera Indonesia. Dalam menghitung freeboard terdapat beberapa koreksi yang perlu dilakukan antara lain koreksi terhadap $\mathrm{Cb}$, koreksi terhadap tinggi kapal, dan koreksi terhadap bangunan atas. Harga freeboard kapal sebesar $1.12 \mathrm{~m}$ sedangkan harga freeboard minimum sebesar 0.343. sehingga freeboard desain telah memenuhi peraturan.

\section{G. Stabilitas}

Stabilitas merupakan salah satu kriteria yang harus dipenuhi pada proses desain kapal. Analisis stabilitas digunakan untuk mengetahui keseimbangan kapal secara melintang atau oleng pada beberapa kriteria kondisi pemuatan (loadcase). Pada perhitungan stabilitas ini dilakukan dengan menggunakan software Maxsurf Educational Version Kriteria stabilitas yang 
digunakan adalah kriteria stabilitas untuk kapal jenis umum dan kapal penumpang yang mengacu pada Intact Stability (IS) Code Reg. III/3.1. Berikut adalah hasil running setelah dilakukannya pemuatan dalam setiap kondisi/loadcase:

Tabel 3.

Summary stabilitas untuk semua loadcase

\begin{tabular}{|c|c|c|c|c|c|c|}
\hline \multirow{2}{*}{ Criteria } & \multirow{2}{*}{ Value } & \multirow{2}{*}{ Unit } & \multicolumn{4}{|c|}{ Actual } \\
\hline & & & 1 & 2 & 3 & 4 \\
\hline $\begin{array}{l}\text { Area } 0 \text { to } 30 \text { shall } \\
\text { be greater than }(>)\end{array}$ & 3.151 & m.deg & 11.38 & 10.107 & 10.081 & 11.127 \\
\hline $\begin{array}{l}\text { Area } 0 \text { to } 40 \text { shall } \\
\text { be greater than }(>)\end{array}$ & 5.157 & m.deg & 16.81 & 14.714 & 14.771 & 16.779 \\
\hline $\begin{array}{l}\text { Area of to } 30 \text { shall } \\
\text { be greater than }(>)\end{array}$ & 1.719 & m.deg & 5.435 & 4.607 & 4.689 & 5.652 \\
\hline $\begin{array}{l}\text { Max GZ at } 30 \\
\text { greater shall be } \\
\text { greater than }(>)\end{array}$ & 0.2 & $\mathrm{~m}$ & 0.589 & 0.519 & 0.529 & 0.616 \\
\hline $\begin{array}{l}\text { Angle of max GZ } \\
\text { shall be greater than } \\
(>)\end{array}$ & 25 & deg & 27.3 & 26.4 & 27.3 & 29.1 \\
\hline $\begin{array}{l}\text { Initial GMt shall be } \\
\text { greater than }(>)\end{array}$ & 0.15 & $\mathrm{~m}$ & 1.605 & 1.426 & 1.423 & 1.581 \\
\hline $\begin{array}{l}\text { Passenger } \\
\text { crowding: angle of } \\
\text { equilibrium. Angle } \\
\text { of steady heel shall } \\
\text { be less than }(<)\end{array}$ & 10 & deg & 0 & 0 & 0 & 0 \\
\hline $\begin{array}{l}\text { Turning: angle of } \\
\text { equilibrium. Angle } \\
\text { of steady heel shall }\end{array}$ & 10 & deg & 0 & 0 & 0 & 0 \\
\hline & & Status & Pass & Pass & Pass & Pass \\
\hline
\end{tabular}

\section{H. Trim}

Trim merupakan kondisi keseimbangan kapal secara memanjang. Trim terjadi karena perbedan letak titik B dan titik $\mathrm{G}$ kapal atau titik berat kapal keseluruhan secara memanjang tidak sama dengan titik berat kapal yang tercelup air, sehingga menyebabkan perbedaan sarat pada bagian depan dan belakang kapal. Pemeriksaan trim ini juga dilakukan dengan menggunakan software Maxsurf Educational Version. Dengan mengacu pada SOLAS Reg. II/7, dimana kondisi trim maksimum yang diperbolehkan adalah $0.5 \%$ Lwl. Berikut adalah hasil running yang dilakukakn untuk melihat hasil trim disetiap loadcase.

Tabel 4.

Summary trim untuk setiap loadcase.

\begin{tabular}{lcccc}
\hline \multirow{2}{*}{\multicolumn{1}{c}{ Kriteria }} & \multicolumn{4}{c}{ Loadcase } \\
\cline { 2 - 5 } & 1 & 2 & 3 & 4 \\
\hline Draft Amidsh m & 1.961 & 1.885 & 1.808 & 1.658 \\
Displacement tonne & 331.1 & 313 & 2959 & 262.1 \\
Heel to Starboard degrees & 0 & 0 & 0 & 0 \\
Draft at FP m & 1.901 & 1.860 & 1.730 & 1.595 \\
Draft to AP m & 2.021 & 1.911 & 1.886 & 1.722 \\
Draft at LCF m & 1.964 & 1.887 & 1.812 & 1.661 \\
Trim (+ve by stern) m & 0.121 & 0.051 & 0.155 & 0.127 \\
WL Length m & 36.534 & 36.011 & 35.789 & 34.822 \\
WL Beam m & 7.960 & 7.947 & 7.934 & 7.897 \\
Block Coeff. & 0.566 & 0.566 & 0.561 & 0.560 \\
LCB from zero pt (+ve fwd) m & 17.723 & 17.901 & 17.790 & 17.966 \\
Koreksi trim (+/- $\leq 5 \%$ Lwl) & 0.1958 & 0.0823 & 0.2522 & 0.2060 \\
\hline \hline
\end{tabular}

\section{Biaya}

Dalam perjitungan biaya, hanya menghitung biaya pembangunan kapal dan biaya operasional karena kapal ini tidak bertujuan untuk komersil (Niaga) tetapi untuk tujuan social. Total biaya pembangunan kapal sebesar Rp. 11.704.435.604 dan total biaya operasional sebesar Rp. 11.241.391.672. per tahun.

\section{J. Lines Plan, Rencana Umum, dan Safety Plan}

Rencana garis merupakan gambaran bentuk lambung kapal yang diproyeksikan menjadi tiga sudut pandang yaitu sudut pandang depan, samping, dan atas. Pembuatan rencana garis menggunakan bantuan software Maxsurf Educatonal Version dan $C A D$ Langkah awal adalah pembuatan model menggunakan software Maxsurf Educational Version. Untuk jenis kapal katamaran digunakan sample design yang terdapat di software untuk model awal. Kemudian dilakukan perubahan pada beberapa elemen antara lain ukuran utama, grid spacing, zero point sesuai dengan kapal yang akan didesain. Untuk mendapatkan kriteria displasemen yang sesuai dengan perhitungan dilakukan editing manual dengan menggeser control point.

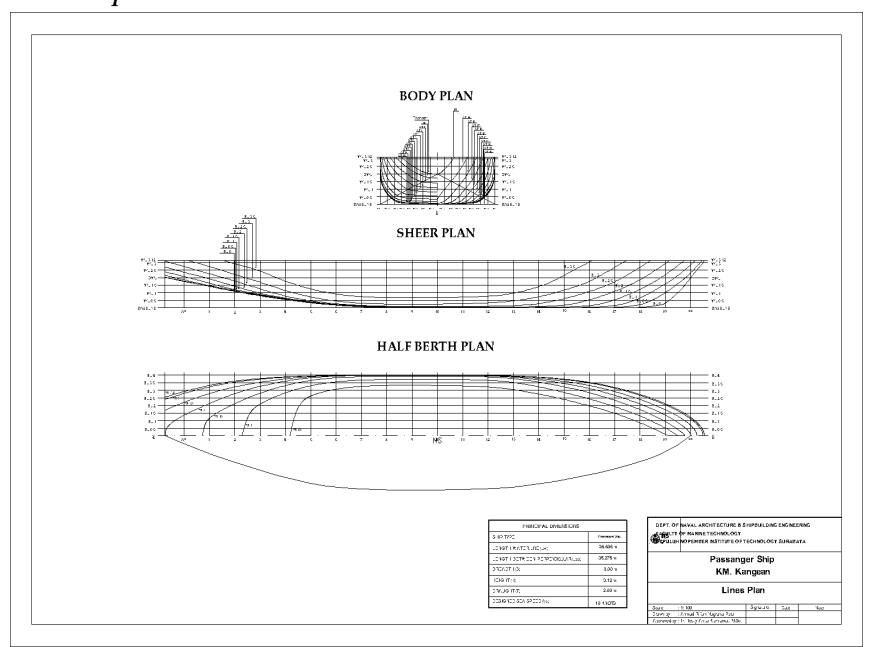

Gambar. 3. Lines plan

Rencana umum merupakan perencanaan ruangan di dalam kapal yang dibutuhkan sesuai dengan fungsi dan perlengkapan kapal. pada pembuatan rencana umum untuk kapal jenis ini disesuaikan dengan peralatan yang dibutuhkan untuk layanan yang telah ada. Secara umum rencana umum digambarkan dalam tiga sudut pandang yaitu tampak depan, tampak samping, dan tampak atas kapal. 


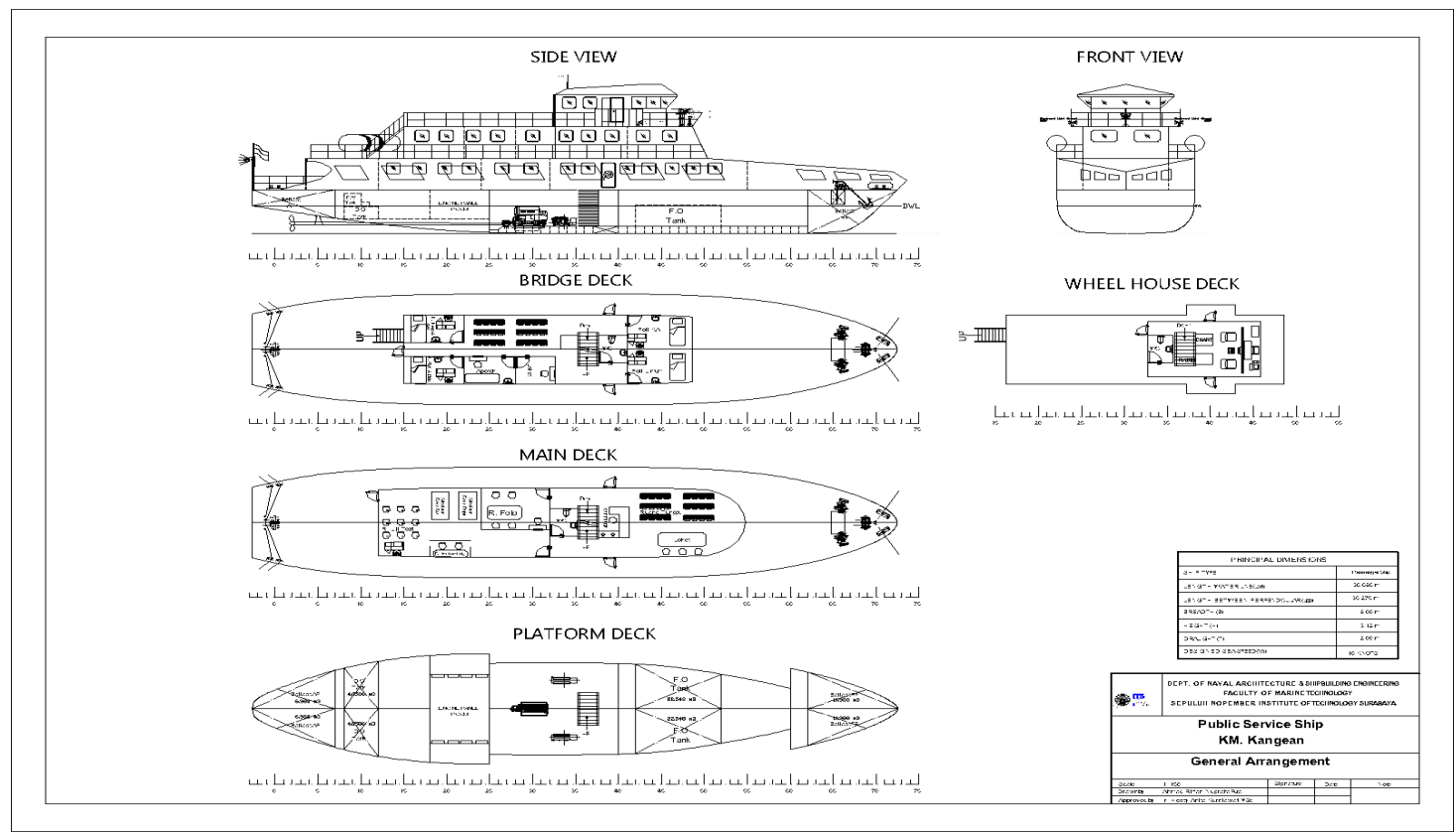

Gambar. 4. General Arrangement

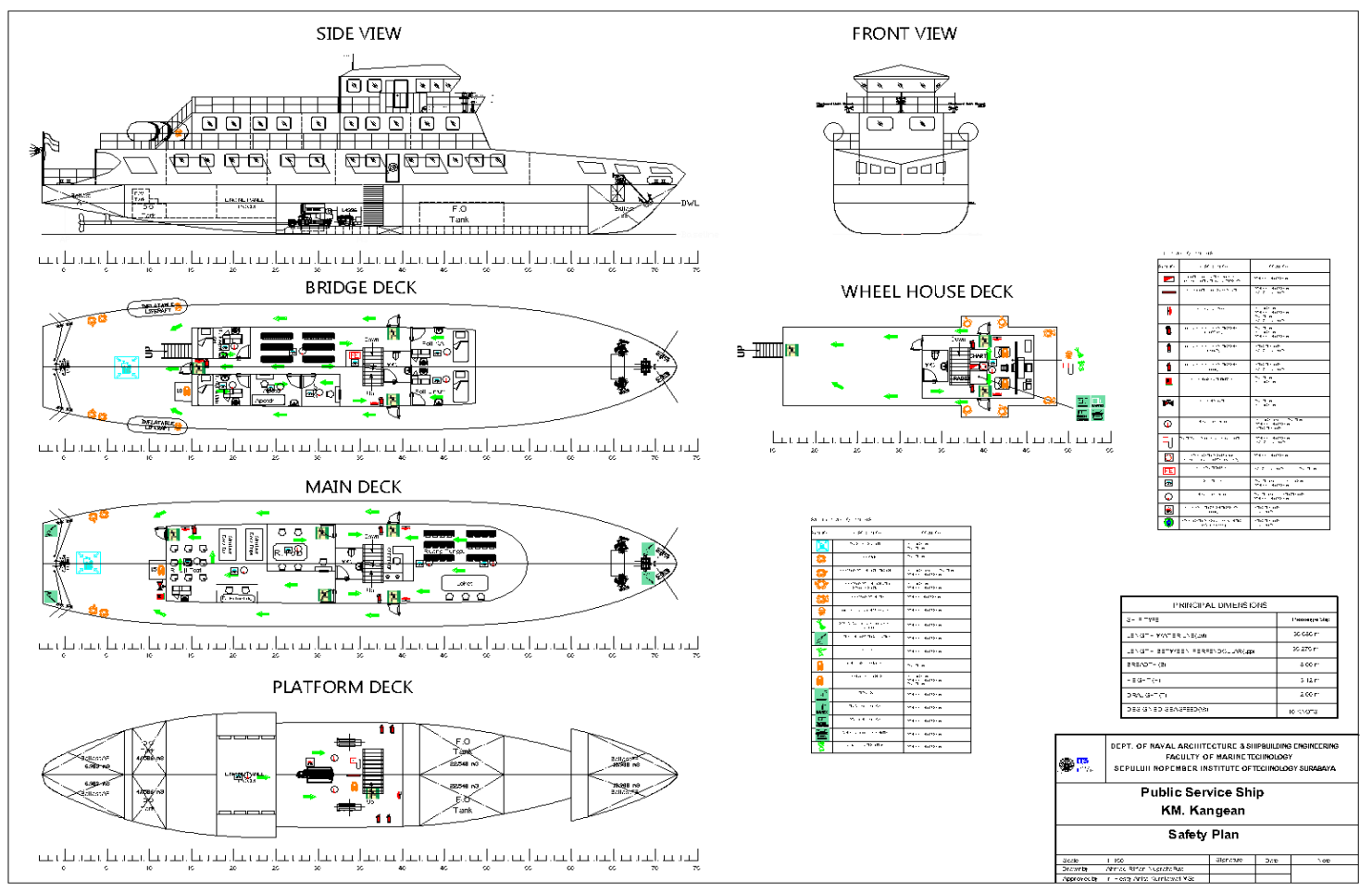

Gambar. 5. Safety Plan

Safety plan adalah perencanaan alat-alat keselamatan, komunikasi, dan navigasi pada kapal. Perencanaan ini tergantung dari peletakan alat-alat diatas. Peletakan peralatan harus berdekatan dengan tempat yang membutuhkan alat tersebut.

\section{K. 3D Kapal}

Pembuatan model kapal ini harus sesuai dengan ukuran utama kapal dengan bentuk lambung yang menyerupai kapal kapal tersebut. Banyak aplikasi yang digunakan dalam membuat model 3 dimensi. Salah satunya adalah menggunakan SketchUp trial version. Berikut ini adalah gambar model 3

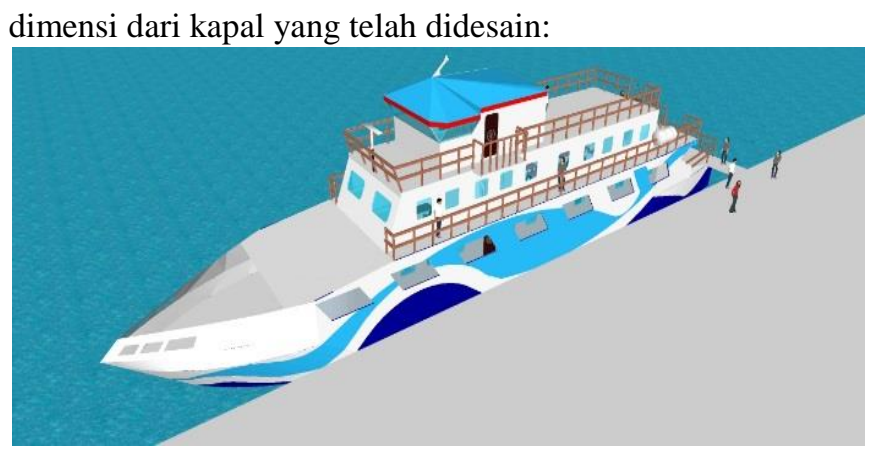

Gambar. 6. 3D kapal tampak samping depan. 


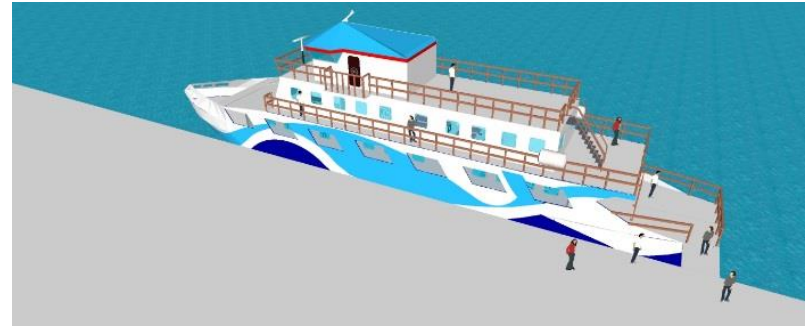

Gambar. 7. 3D kapal tampak samping belakang.

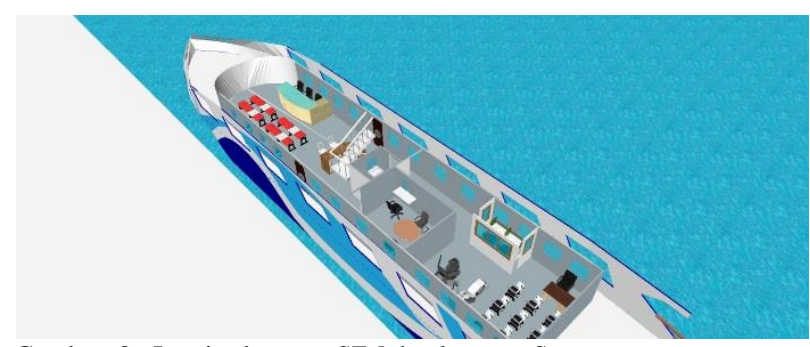

Gambar. 8. Interior layanan SIM dan layanan Samsat.

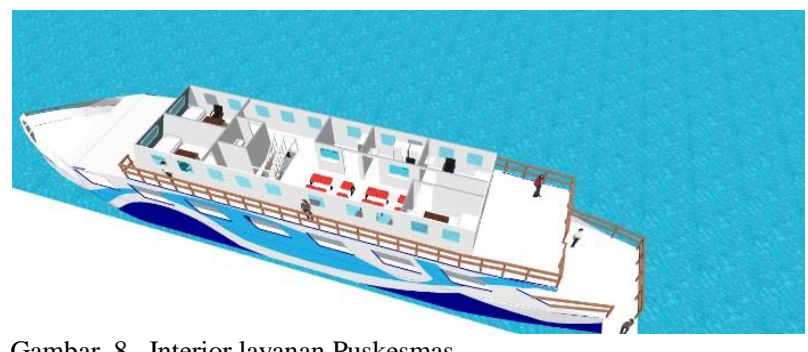

Gambar. 8. Interior layanan Puskesmas.

\section{KESIMPULAN}

Pada jurnal ilmiah ini dilakukan analisis secara teknis dan ekonomis pada kapal KM. Kangean. Berdasarkan hasil analisis yang telah dilakukan dapat disimpulkan bahwa kapal ini memenuhi dari aspek teknis maupun ekonomis dan diambil kesimpulan sebagai berikut:

1) Desain awal dan payload didapatkan dari survei lapangan, dengan jumlah payload sebanyak 61 orang atau sama dengan 4.575 ton.
2) Setelah dilakukan validasi stabilitas, didapatkan ukuran utama akhir kapal yaitu:

$\begin{array}{lllll}\text { Lpp } & : & 35.275 \mathrm{~m} & \text { Displasmen } & : 341.618 \\ \text { ton } & \\ \mathrm{B} & : \quad 8 \mathrm{~m} & \begin{array}{l}\text { Kecepatan } \\ \text { Dinas }\end{array} & : 10 \text { knot } \\ \mathrm{H} & : \quad 3.12 \mathrm{~m} & \begin{array}{l}\text { Jumlah } \\ \text { Mesin Induk }\end{array} & : 1 \\ \mathrm{~T} & : \quad 2 \mathrm{~m} & \begin{array}{l}\text { Power } \\ \text { Mesin Induk }\end{array} & \begin{array}{l}: 315 \mathrm{HP} \\ \text { waktu }\end{array}\end{array}$

3) Biaya pembangunan kapal adalah sebesar Rp. 11.704.435.604 dan biaya operasional sebesar Rp. 11.241.391.672.

\section{UCAPAN TERIMA KASIH}

Ucapan terima kasih Penulis tujukan yang pertama kepada Ibu Ir. Hesty Anita Kurniawati, M.Sc selaku dosen pembimbing, Bapak Aries Sulisetyono, S.T., MA.Sc, Ph.D, sebagai dosen wali Penulis. Kedua kepada Ayah dan Ibu yang telah memberikan do'a dan segalanya untuk menyelesaikan penelitian ini, Kedua saudara dan Meriem Octaviana yang selalu ada disetiap kondisi apapun. Ketiga kepada teman-teman dan pihak-pihak yang tidak dapat Penulis sebutkan satu persatu.

\section{DAFTAR PUSTAKA}

[1] I. D. Pratama, "Perancangan Kapal Layanan Masyarakat di Kepulauan Seribu," Surabaya: Jurusan Tekniki Perkapalan, FTK, ITS, 2013.

[2] R. Taggart, Ship Design and Construction, Chapter 5 Section 3, SNAME, 1980.

[3] Hallopolisi.com, Sabtu Mei 2016. [Online]. Available: www.hallopolisi.com: http://halopolisi.com/tag/sim-keliling/. [Diakses Sabtu Mei 2016].

[4] A. R. Dwiyatcita, "Perancangan Kapal Trimaran Untuk Kapal Puskesmas Keliling Di Daerah Kepulauan : Studi Kasus Kepulauan Kangean, Madura'," Surabaya: Jurusan Teknik Perkapalan, FTK, ITS, 2013.

[5] H. Schneekluth, Ship Design for Efficiency and Economy, Oxford: Plant A Tree, 1998. 